\title{
The Reliance on Lifestyle Audits for Public Officials to Curb Corruption and Tax Evasion in Nigeria
}

\author{
O Animashaun* and H Chitimira**
}

\section{P.E.R}

Pioneer in peer-reviewed, open access online law publications

Authors

Oyesola Animashaun

Howard Chitimira

Affiliation

North-West University,

South Africa

Email

anitrust2@gmail.com

Howard.Chitimira@nwu.ac.za

Date Submission

28 October 2020

Date Revised

31 May 2021

Date Accepted

31 May 2021

Date published

17 January 2021

Editor Dr TV Warikandwa

How to cite this article

Animashaun $\mathrm{O}$ and Chitimira $\mathrm{H}$

"The Reliance on Lifestyle Audits for Public Officials to Curb

Corruption and Tax Evasion in Nigeria" PER / PELJ 2021(24) DOI

http://dx.doi.org/10.17159/1727-

$3781 / 2021 / v 24 i 0 a 10735$

\section{Copyright}

DOI

http://dx.doi.org/10.17159/17273781/2021/v24i0a10735

\begin{abstract}
Widespread corruption in the Nigerian public service is having a far-reaching detrimental effect on the economy. Public officers and other policy makers that formulate socio-economic policies are the main perpetrators of corruption in Nigeria. This article focusses on the viability of lifestyle audits for public officials as a strategy for combating such corruption, the proceeds of which are usually laundered and warehoused either offshore or in Nigeria with the assistance of professionals such as bankers and lawyers. If such warehoused wealth is discovered it is usually forfeited to the treasury of the government of Nigeria, after the trial of the offenders. This article interrogates the adequacy of the relevant legislation and the efficacy of the statutory bodies responsible for lifestyle audits in Nigeria, such as the Code of Conduct Bureau, which is discussed, as are the Code of Conduct Bureau and Tribunal Act, 2010, the Economic and Financial Crimes Commission Act, 2004, and the income tax reporting framework administered by the Federal Inland Revenue Service. It appears that the provisions relating to lifestyle audits under the Nigerian statutes are not robust enough to curb corruption and tax evasion. In addition, the enforcement of such lifestyle audits is hindered by the immunity granted to certain Nigerian public officers and jurisdictional conflicts in prosecuting corruption cases.
\end{abstract}

\section{Keywords}

Lifestyle audits; public officers; corruption; tax evasion; technology. 


\section{Introduction}

No society is immune from corruption. However, the high levels of corruption in the Nigerian public service have created numerous socio-economic and political challenges in the society and economy. Corruption has given rise to poor economic growth, poverty and insecurity. ${ }^{1}$ Issues of corruption have dominated Nigerian politics and public discourse since the country's return to democratic government in 1999. Successive civilian governments since 1999 have formulated and implemented policies and legislation aimed at curbing corruption. However, notwithstanding such efforts, corruption is commonplace. ${ }^{2}$ Nigeria ranked $130^{\text {th }}$ out of 180 countries, with 26 per cent on the corruption index perspective in $2019 .{ }^{3}$ Corruption is undoubtedly the most pressing governance and development challenge that Nigeria is confronted with today because it fraudulently transfers public goods and services into private pockets. Corruption in the public sector remains a problem in Nigeria's quest to inculcate transparency and accountability in its public officials. ${ }^{4}$ The failure to deliver social services, the endemic problem of power supply and the collapse of infrastructure are all linked to corruption $^{5}$ in all tiers of the Nigerian government. ${ }^{6}$

* $\quad$ Oyesola Animashaun. LLB (Lagos State University) LLM (Ogun State University) PhD (University of llorin). Postdoctoral fellow, Faculty of Law, North-West University, South Africa. Email: anitrust2@gmail.com. ORCiD: https://orcid.org/0000-00023942-6266.

** Howard Chitimira. LLB (cum laude) LLM (UFH) LLD (NMMU). Research Professor and Professor of Securities and Financial Markets Law, Faculty of Law, North-West University, South Africa. Email: Howard.Chitimira@nwu.ac.za. ORCiD: https://orcid.org/0000-0003-1881-1242.

1 Gaspar, Mauro and Medas 2019 https://www.weforum.org/agenda/2019/04/tacklingcorruption-in-government/ 1-3; Hoffmann and Patel Collective Action on Corruption in Nigeria ix-x; Martini and Chêne 2014 https://www.transparency.org/files/ content/corruptionqas/Approaches_to_curbing_corruption_in_tax_administration_in Africa_2014.pdf 2-8; Onuigbo and Eme 2015 AJBMR 18; Alemika et al 2015 https://nigeria.actionaid.org/sites/nigeria/files/pc_report_content.pdf 46-56; Aluko "Corruption in Nigeria" 1-4; Vannucci 2009 Bulletin of Italian Politics 233-235; Ogbu 2008 Ann Surv Int'l \& Comp L 99; Mahesh "Corruption in Tax Administration" 285.

2 UNODC 2019 https://www.unodc.org/documents/data-and-analysis/statistics/ corruption/nigeria/Corruption_in_Nigeria_2019_standard_res_11MB.pdf_10; D'Arcy and Cornell 2016 African Affairs 253; Kelly Corruption in Africa 13-16; Andvig Corruption in Sub-Saharan Africa 19.

3 Transparency International 2020 https://www.transparency.org/files/content/ pages/2019_CPI_Report_EN.pdf 3.

4 Alemika et al 2015 https://nigeria.actionaid.org/sites/nigeria/files/pc_report content.pdf 6.

$5 \quad$ Schlenther 2017 eJournal of Tax Research 218; UNECA and AUABC 2017 https://repository.uneca.org/bitstream/handle/10855/23273/Bib-28380.pdf 2-5.

6 Alemika et al 2015 https://nigeria.actionaid.org/sites/nigeria/files/pc_report content.pdf 16. 


\section{Definitional aspects}

Corruption is difficult to define and almost impossible to measure due to the concealed nature of corrupt practices and their multifarious manifestations or diverse forms. ${ }^{7}$ For instance, Brooks et al argue that the concealed nature of corruption rarely leaves any obvious trail. ${ }^{8}$ Unlike other crimes such as homicide or robbery, there are often no witnesses involved when crimes involving corruption are committed. Direct victimisation caused through corrupt activity may neither be immediately nor individually felt, and the public may be therefore unaware of the occurrence of such corrupt activity. Against this backdrop, Brooks et al argue that attempting to define corrupt transactions and undertaking its measurement are difficult ventures. ${ }^{9}$ Transparency International defines corruption as "the abuse of entrusted power for private gain". ${ }^{10}$ In a similar context, Schlenther, and Abiloro, Olawole and Adeniran submit that corruption is the transfer of interest from the public for personal gain or the abuse of public office for an individual's private benefit. ${ }^{11}$ The authors concur with this definition for the purposes of this article. The Corrupt Practices and Other Related Offences Act, 2004 defines corruption to include bribery, fraud and other related offences. ${ }^{12}$ The Corrupt Practices Act defines corruption by its manifestations, thus underscoring the fact that corruption is difficult to define.

The United Nations Convention against Corruption defines the term "public official" as any person holding a legislative, executive, administrative or judicial office or office in a public agency or public enterprise. ${ }^{13}$ It may also refer to any other person defined as a "public official" in a domestic law of a state. ${ }^{14}$ The Corrupt Practices Act defines a "public officer" as a person

7 Brooks et al Preventing Corruption 27-43; USIP 2010 https://www.usip.org/sites/default/files/Adan/NPEC1011_StudyGuide_combined.pdf 4-5; UNECA $2016 \quad$ https://repository.uneca.org/bitstream/handle/10855/ 23012/b11560794.pdf 11-12; IMF Corruption 3; Rose-Ackerman 2002 Focus on Crime and Society 6.

8 Brooks et al Preventing Corruption 27-43; USIP 2010 https://www.usip.org/sites/default/files/Adan/NPEC1011_StudyGuide_combined.pdf 4-5; UNECA $2016 \quad$ https://repository.uneca.org/bitstream/handle/10855/ 23012/b11560794.pdf 11-12; IMF Corruption 3; Rose-Ackerman 2002 Focus on Crime and Society 6.

$9 \quad$ Brooks et al Preventing Corruption 27-43.

10 Transparency International $2020 \mathrm{https}: / / \mathrm{www}$.transparency.org/en/what-is-corruption 1.

11 Abiloro, Olawole and Adeniran 2019 IJARAFMS 304-319; Schlenther 2017 eJournal of Tax Research 219; Ambar 2015 JEF 106-111.

12 Section 2 of the Corrupt Practices and Other Related Offences Act Chapter C31 LFN 2004 (Corrupt Practices Act).

13 Article 2(a) of the United Nations Convention against Corruption (2004).

14 Article 2(a) of the United Nations Convention against Corruption (2004). 
employed or engaged in any capacity in the public service of the federation, state or local government, or in any public corporations. ${ }^{15}$ This definition is adopted for the purposes of this article. The article focusses on the public sector because it plays a pivotal role in the formulation and implementation of policies that affect both the public and the private sectors. ${ }^{16}$ In essence, the public sector drives the practice of corruption in Nigeria, since it is responsible for the formulation and implementation of the overall socioeconomic and political policies. Moreover, the public sector is directly involved in the prevention and detection of crime as well as the prosecution and conviction of criminals in Nigeria. In this regard, the Economic and Financial Crime Commission Act, $2004^{17}$ stipulates that economic crime includes corruption and tax evasion and non-violent criminal and illicit activity committed with the aim of acquiring wealth from illicit sources. Economic crimes also include any form of fraud, narcotic drug trafficking, money laundering, embezzlement, bribery, looting and any form of corrupt practices, tax evasion and other such transactions. ${ }^{18}$ The difficulty in defining the term "corruption" could have led to the emergence of many variants of corruption in Nigeria.

Evans argues that the interrelationship between tax and corruption has both positive and negative outcomes. ${ }^{19}$ For instance, a well-developed tax system can provide a good regulatory framework and institutional foundations which can help to combat corrupt practices. Furthermore, a well-developed tax system can increase the availability of ownership information and discourage the use of shell companies and other opaque legal arrangements which conceal the identity of the true owners of such companies to curb corruption and tax evasion. ${ }^{20}$ Similarly, the elimination of strict bank secrecy for tax purposes is likely to reduce corruption and tax evasion in Nigeria. ${ }^{21}$ A good tax system could further discourage money laundering and corruption. Corruption reduces tax compliance. For instance, a society that is corrupt may enable tax evasion because some tax officials may seek bribes from taxpayers and that could reduce tax

15 Section 2 of the Corrupt Practices Act; see also Egobueze and lyalla 2020 IJSSH 7.

16 See Van Vuuren "South Africa: Democracy, Corruption and Conflict Management" 4.

17 Section 46 of the Economic and Financial Crimes Commission Act Chapter E1 LFN 2004 (Economic and Financial Crimes Commission Act).

18 Section 46 of the Economic and Financial Crimes Commission Act.

19 Evans 2017 eJournal of Tax Research 140.

20 OECD 2021 https://www.oecd.org/tax/centre-for-tax-policy-and-administrationbrochure.pdf 19.

21 OECD 2021 https://www.oecd.org/tax/centre-for-tax-policy-and-administrationbrochure.pdf 20. 
revenue. ${ }^{22}$ According to Evans, the relationship between tax and corruption is both complex and critical. ${ }^{23}$ This follows the fact that corruption negatively affects the overall tax revenue, and the more corrupt a state is, the less the tax revenue collected. ${ }^{24}$ States that do not raise adequate revenues are unable to build institutions to support economic development. Consequently, corruption weakens tax compliance and reduces the volume of tax revenues that could be recouped by the Nigerian tax authorities. ${ }^{25}$

Taxation refers to the pecuniary burden imposed on properties, income or commodities, activities or transactions of natural and juristic individuals by the government in order to generate revenue in Nigeria, and tax evasion is the illegal and intentional non-payment or underpayment of tax. ${ }^{26}$ Although tax evasion is our main concern in this article, it must be distinguished from tax avoidance. The former is the illegal underpayment or non-payment of tax by concealing or misrepresenting the nature of a transaction, while the latter admits the transaction but the transactions are arranged in such a way that the tax payable is lower. ${ }^{27}$ Notwithstanding the difference in the definition and treatment of tax avoidance and evasion, the outcome is essentially the same: that is, the loss of revenue to the government treasury. ${ }^{28}$ Alm, Martinez-Vazquez and McClellan ${ }^{29}$ argue that corruption facilitates tax evasion by making it easier for taxpayers to conceal their income. In addition, bribes enable higher levels of tax evasion by taxpayers, who bribe tax officials to escape higher assessments.

Lifestyle audits have been described by Coenen, and Munjeyi and Mujuru as suspect profiling and intelligence background investigations and net worth analysis. ${ }^{30}$ This description adequately captures the essence of lifestyle audits in Nigeria, which are used to determine whether the lifestyle of public officials corresponds to their known legitimate sources of income to ascertain whether the official under investigation has been engaging in

22 Alm, Martinez-Vazquez and McClellan $2016 \mathrm{~J}$ Ec Behav \& Org 146; Rosid, Evans and Tran-Nam 2016 eJournal of Tax Research 387; Alm 2012 http://repec.tulane.edu/RePEc/pdf/tul1213.pdf 16-17.

23 Evans 2017 eJournal of Tax Research 140.

24 Baum et al 2017 eJournal of Tax Research 190-216.

25 Baum et al 2017 eJournal of Tax Research 190-216; UNECA and AUABC 2017 https://repository.uneca.org/bitstream/handle/10855/23273/Bib-28380.pdf 3-7.

26 Ozili 2020 Journal of Financial Crime 532; Slemrod 2007 JEP 26.

27 Christians 2017 JOTA 10; Croome and Croome Street Smart Taxpayers 223, 272.

28 Christians 2017 JOTA 12; Karlsson and Matthiasson 2015 Nordic Tax Journal 16; Otusanya 2010 CPA 316.

29 Alm, Martinez-Vazquez and McClellan 2016 J Ec Behav \& Org 161-162.

30 Munjeyi and Mujuru 2018 IJIRSET 8632; Coenen Expert Fraud Investigation 171; Van Rooyen Practitioner's Guide to Forensic Investigation 216. 
corrupt practices. Where the subjects of the audit are found to be living well beyond their known means, investigators will suspect that the affected officials have illicit sources of income. ${ }^{31}$ Lifestyle audits are also used by auditors to ascertain if the income claimed by the public officials on their tax returns corresponds to their lifestyles..$^{32}$ In Nigeria lifestyle audits are not provided for in a specific statute. As a result, various provisions in different statutes such as the Code of Conduct Bureau and Tribunal Act ${ }^{33}$ and the Federal Inland Revenue Services (Establishment) $A_{c}{ }^{34}$ are instead utilised. A lifestyle audit is one of the strategies which has been employed to stem corruption but it has failed to effectively curb the increasing levels of corruption in Nigeria, especially in the public sector. A major reason for this is the failure of the relevant authorities to adopt and integrate technology, as well as the lack of political will on the part of top government officials to tackle corruption in all its ramifications. For instance, the former AuditorGeneral of Nigeria (Mr Azie) submitted a report on the profligacy of the executive to the National Assembly (Nigeria Federal Parliament) on 10 January 2003. This incriminatory report was believed to have led to the Auditor-General's abrupt retirement on controversial grounds. ${ }^{35}$ The removal of the Auditor-General from office before the expiration of his term may be an indicator of the fact that the executive arm of the Nigerian government was not comfortable with the audit which revealed its wrongdoings.

The corruption in the Nigerian public sector is a major problem and an issue of great concern to ordinary Nigerians and the international community. ${ }^{36}$ For instance, a forensic audit conducted by the audit firm of PriceWaterhouseCoopers (PwC) in 2015 revealed that a sum of 1.48 billion United States of America dollars (US\$) was unaccounted for in the Nigerian National Petroleum Corporation's (NNPC) account because it had not been remitted to the Nigerian federation account. ${ }^{37}$ The NNPC is the body which

31 InvestorWords Date Unknown http://www.investorwords.com/10191/lifestyle_ audit.html 1.

32 Munjeyi and Mujuru 2018 IJIRSET 8632.

33 Section 15 of the Code of Conduct Bureau and Tribunal Act Chapter C15 LFN 2010 (Code of Conduct Bureau and Tribunal Act).

34 Sections 26-39 of the Federal Inland Revenue Services (Establishment) Act 13 of 2007.

35 Akhidime and Izedonmi 2012 USV Ann Econ Publ Adm 187; Vanguard Editor 2003 https://allafrica.com/stories/200302250568.html 11; Phillip 2003 https://allafrica.com/stories/200303240846.html 2.

36 ljewereme 2015 SAGE Open 3-5.

37 Amaefule and Umeaka 2016 IJIDPS 8. 
regulates the country's petroleum industry. ${ }^{38}$ Given this background, the article explores the viability of lifestyle audits as a strategy for combating and preventing corruption and consequently tax evasion in Nigeria.

\section{Corruption and tax evasion in Nigeria}

Corruption in the Nigerian public sector is currently very difficult to detect and for the enforcement authorities to curb. It is also submitted that the law enforcement agents themselves are reputed to be the main perpetrators of corruption. ${ }^{39}$ Corruption is the greatest obstacle preventing Nigeria from achieving its enormous potential with regard to the provision of public goods and services, because it drains billions of dollars annually from the country's economy. ${ }^{40}$ Corruption impedes development and weakens the social contract between the Nigerian federal government and its people. ${ }^{41}$ It is pervasive in Nigeria. Michael Page categorises it on the basis of diverse criteria such as the scale of occurrence, the sector in which it is prevalent, and the tactics and behaviours used in perpetrating it. ${ }^{42}$ "Grand corruption" or "political corruption" refers to the corrupt practices committed by high government officials, which distort policies and the proper functioning of the state to benefit a few public officials at the expense of the public good. ${ }^{43}$ "Petty corruption" is everyday abuse perpetrated by low- and mid-level public officials in their interactions with ordinary citizens who are trying to access public goods and services. ${ }^{44}$ Page further classified corruption in Nigeria with reference to motivations such as greed, patronage or financial need, or according to its relative social acceptability or harmfulness. ${ }^{45}$

According to Farida Waziri (a former chairman of the Economic and Financial Crimes Commission (EFCC)), policy makers in Nigeria have

38 Sections 5, 6, 10 and 11 of the Nigerian National Petroleum Corporation Act Chapter N123 LFN 2004.

39 Page 2018 https://carnegieendowment.org/2018/07/17/new-taxonomy-for-corruptionin-nigeria-pub-76811 1-2; Alege et al 2014 GJISS 212-213; Okolo and Raymond 2014 GJHSS 30-36.

40 Page $2018 \mathrm{https}: / /$ carnegieendowment.org/2018/07/17/new-taxonomy-for-corruptionin-nigeria-pub-768112.

41 Page $2018 \mathrm{https}: / /$ carnegieendowment.org/2018/07/17/new-taxonomy-for-corruptionin-nigeria-pub-76811 2-3; Abu and Staniewski 2019 Economic Research 3058-3061.

42 Page 2018 https://carnegieendowment.org/2018/07/17/new-taxonomy-for-corruptionin-nigeria-pub-76811 1-4; Aluko "Corruption in Nigeria" 2-4.

43 PwC 2016 https://www.pwc.com/ng/en/assets/pdf/impact-of-corruption-on-nigeriaseconomy.pdf 7.

44 PwC 2016 https://www.pwc.com/ng/en/assets/pdf/impact-of-corruption-on-nigeriaseconomy.pdf 7.

45 Page 2018 https://carnegieendowment.org/2018/07/17/new-taxonomy-for-corruptionin-nigeria-pub-76811 3-6; Aluko "Corruption in Nigeria" 2-6. 
implemented many policy options to fight corruption in the public sector over the years, but these measures have been largely ineffective ${ }^{46}$ because of a lack of political will on the part of the executive. The lack of and/or poor use of technological measures to enforce lifestyle audits constitute a major impediment to the curbing of corruption in Nigeria. The poor enforcement of the relevant laws also contributes to the commission of corruption in the Nigerian public service sector. Some of the policy measures aimed at checking corruption are found in the Public Officers Protection Act Chapter P41 LFN 2004, the Public Officer Investigation of Assets Decree 54 of 1976, the Forfeiture of Assets Decree 53 of 1999, the Failed Bank Tribunal Decree, 1996, the Code of Conduct for Public Officers Chapter C15 LFN 2004 and the Constitution of the Federal Republic of Nigeria, 1999 (the Constitution). ${ }^{47}$ Other efforts aimed at combating corruption in Nigeria include the enactment of the Corrupt Practices and Other Related Offences Act in $2000,{ }^{48}$ and the Economic and Financial Crimes Commission Act in $2003 .{ }^{49}$ Despite these measures, Nigeria is still rated as one of the most corrupt countries in the world, because corruption is still rife in the public service sector..$^{50}$ Thus, Nigeria is unable to generate sufficient revenue from taxation because it faces a number of institutional problems such as corruption. ${ }^{51}$

The payment of tax is an obligation which natural and juristic persons owe to the state in conformity with section 24(4) of the Constitution. Nevertheless, corruption impacts negatively on the tax administration when tax officials accept or solicit bribes in exchange for lower tax assessments. ${ }^{52}$ Consequently, corruption in the tax administration is a serious concern in many jurisdictions, including Nigeria, where corruption usually involves practices such as paying bribes in exchange for understating liability and avoiding registration or extorting taxpayers through threats of overassessment. ${ }^{53}$ Corruption also has a negative effect on the tax operating

$46 \quad$ Waziri Corruption and Governance Challenge 7.

47 Part 1 of the Fifth Schedule to the Constitution of the Federal Republic of Nigeria, 1999 Chapter C23 LFN 2004 (the Constitution).

48 Corrupt Practices and Other Related Offences Act Chapter C31 LFN 2004.

49 Economic and Financial Crimes Commission Act Chapter E1 LFN 2004.

50 Ugwu and Gordon 2018 JSC 119; ljewereme 2013 Quarterly Journal of Administration 108-127; Aluko "Corruption in Nigeria" 2-6; Transparency International 2020 https://www.transparency.org/files/content/pages/2019_CPI_Report_EN.pdf 3.

51 Ajaz and Ahmad 2010 Pak Dev Rev 405-406; Jack-Osimiri and Kokpan "Fraud and Corruption in Nigerian Taxation" 4-6.

52 UNODC $2019 \quad \mathrm{https} / / \mathrm{www}$.unodc.org/documents/data-andanalysis/statistics/corruption/nigeria/Corruption_in_Nigeria_2019_standard_res_11M B.pdf $41-44$.

$53 \quad$ Schlenther 2017 eJournal of Tax Research 218. 
environment, reduces the compliance levels and increases the quantum of tax evasion. ${ }^{54}$ Therefore, the Nigerian federal government should promote transparency and accountability through the employment of technology and the digitalising of transactions to curb corruption and tax evasion. For instance, Okunogbe and Pouliquen argue that the adoption of electronic tax filing (e-filing) in developing countries decreases tax evasion and corruption. ${ }^{55}$ Schlenther also argues that corruption and tax evasion are interrelated because corrupt networks allow and facilitate the illegal flow of funds, money laundering schemes and tax evasion. ${ }^{56}$ The authors concur with this assertion and argue further that corruption is exacerbated by the lack of and/or poor use of technology to detect and curb it in Nigeria.

Alm, Martinez-Vazquez and McClellan argue that corruption enables tax evasion by making it easier for taxpayers to hide their income. ${ }^{57}$ Thus, widespread corruption affects tax compliance and increases tax evasion. ${ }^{58}$ Corruption also negatively affects tax revenue collection. ${ }^{59}$

\section{The role of lifestyle audits in combating corruption and tax evasion in Nigeria}

The main ground for instituting lifestyle audits in the context of this article is to ascertain whether public officials' living standards are consistent with their lawfully obtained income. Lifestyle audits could serve as justifiable measurements of the extent of corruption in the Nigerian public service. For instance, the conviction of the former governor of Bayelsa State (Mr DSP Alamieyeseigha) on the charges of false assets declarations and money laundering were the main grounds for the forfeiture, recovery and repatriation of the assets he corruptly acquired in a case instituted against him in the United Kingdom by the Nigerian government. ${ }^{60}$ In Nigeria $v$ Santolina Investment Company ${ }^{61}$ it was relatively easy to get a conviction against Alamieyeseigha because he made a false declaration of assets. Thus, in this particular case a lifestyle audit helped in proving the case of

54 Schlenther 2017 eJournal of Tax Research 218; Alm and Liu 2017 eJournal of Tax Research 172; Odeku 2019 JLERI 4.

55 Okunogbe and Pouliquen 2018 http://pubdocs.worldbank.org/en/ 754541528721176191/Okunogbe-Pouliquen-EfilingTaj-2018May21.pdf 1-3.

56 Schlenther 2017 eJournal of Tax Research 218.

57 Alm, Martinez-Vazquez and McClellan 2016 J Ec Behav \& Org 161-162; Schlenther 2017 eJournal of Tax Research 220; Tanzi 2017 eJournal of Tax Research 144.

58 Baum et al 2017 eJournal of Tax Research 191-192.

59 Besley and Persson 2014 JEP 114-116; Tanzi and Davoodi "Corruption, Public Investment, and Growth" 280-299; IMF Corruption 6.

$60 \quad$ Nigeria v Santolina Investment Company [2007] EWHC 437 (Ch) paras 73-74.

61 Nigeria v Santolina Investment Company [2007] EWHC 437 (Ch) paras 73-74. 
corrupt enrichment against the defendant, leading to his eventual conviction. All public officials in Nigeria are compelled under section 185(1) of the Constitution to file an asset declaration with the Code of Conduct Bureau (CCB) at the inception and the end of their periods of tenure.

There are many methods such as the net worth method and the administration of a lifestyle questionnaire employed by auditors to detect public officials who are receiving more than their legitimate incomes. The net worth method is commonly used in lifestyle audits and it refers to the difference between assets and liabilities at particular points in time, usually conducted at the inception and the end of the tenure of a public servant. ${ }^{62}$ For career public servants in Nigeria, it is conducted every four years. ${ }^{63}$ If there are differences between the public official's net worth and the legitimately known income of that official, the additional assets are deemed to have been acquired from unlawful or unknown sources, a fact which may point to corruption unless otherwise explained. ${ }^{64}$ This method gives evidence of income that may be hidden. ${ }^{65}$

The second method of conducting lifestyle audits is through surveillance. Surveillance involves unannounced physical visits and/or the use of sophisticated technological equipment to gather information about the person being investigated and audited. In Jim-Jaja v COP66 it was held that the powers of the police must be exercised lawfully so that if there is a reasonable ground to embark on the surveillance of citizens, the permission of the courts must be sought first. Surveillance is the method most preferred by law enforcement agencies such as the Nigeria Police Force in gathering valuable financial information to curb corruption. ${ }^{67}$ The third method of conducting lifestyle audits is the administration of a lifestyle questionnaire on public officials. The questionnaire asks various questions about an individual's lifestyle, the total assets, the liability owed, how the assets were acquired and the source of the funds used to acquire the assets. ${ }^{68}$ The issuance of questionnaires may be triggered by various incidents including the submission of incorrect tax returns to the revenue authority or due to the reporting of any suspected corruption transactions or the possession of

62 Coenen Expert Fraud Investigation: Step-by-Step Guide 10-13; see s 15 of the Code of Conduct Bureau and Tribunal Act.

63 Section 15 of the Code of Conduct Bureau and Tribunal Act; Fjeldstad and Moore 2009 JMAS 1-18.

64 Coenen Expert Fraud Investigation: Step-by-Step Guide 172.

65 Turner Money Laundering Prevention 71.

66 Jim-Jaja v COP (2011) 2 NWLR (pt 1231) 375.

67 Ojukwu Discovering the Police 66.

68 Sections 15-17 of the Code of Conduct Bureau and Tribunal Act. 
unexplained wealth. ${ }^{69}$ This method is the most prevalent method of lifestyle audit in Nigeria. The CCB issues lifestyle audit forms to all public servants to complete and submit to the CCB at the beginning and the end of their tenure of office. ${ }^{70}$ The forms are manually completed and submitted to the CCB. It is submitted that lifestyle audit forms should be administered and completed electronically for transparency and efficiency purposes. This could save time and effort for the CCB employees, who are often tasked with the onerous duties of locating records, scanning, sorting and exporting images or texts, and returning the documents to their correct locations. Currently, it is very difficult to manually scan through and analyse the millions of forms submitted from different ministries, departments, agencies and public corporations.

\section{Legal and institutional responses to corruption in Nigeria through lifestyle audits}

Part 1 of the Fifth Schedule to the Constitution mandates public servants to maintain a high standard of morality, transparency and accountability in the conduct of government business. To this effect, section 6(1) of the Fifth Schedule to the Constitution restricts public officers from asking or accepting any property or benefit of any kind, either for themselves or any other person, while discharging their duties. However, the Constitution allows a public officer to accept personal gifts or benefits from friends and relatives in the context of cultural practice. ${ }^{71}$ This provision is unnecessary and likely to encourage corruption. Section 15(5) of the Constitution provides that the Nigerian state should abolish corrupt practices and the abuse of power by the state and its functionaries. Section 15(5) of the Constitution does not provide for the different types of corrupt practices that the Nigerian state may prohibit. However, this may be inferred from subsidiary legislation such as the Economic and Financial Crime Commission Act. ${ }^{72}$ Sections 140(1) and 185(1) of the Constitution provide that a person elected to the office of president or as a governor of a state in Nigeria shall not begin to perform the functions of that office until he or she has declared his or her assets and liabilities to the CCB. ${ }^{73}$ This provision allows records of the properties of political office holders to be compared to ascertain whether they acquired their assets legitimately. The CCB also

\footnotetext{
Jayawickrama, Pope and Stolpe 2001 Forum on Crime and Society 24.

Section 15-17 of the Code of Conduct Bureau and Tribunal Act.

Sections 6(1)-(3) of Part I of the Fifth Schedule to the Constitution.

Section 46 of the Economic and Financial Crimes Commission Act.

Also see ss 149 and 194 of the Constitution, which makes similar provisions for federal ministers and commissioners in the state government.
} 
makes it mandatory for public officers to declare their assets immediately after taking office and at the end of their periods of tenure. ${ }^{74}$ Similarly, the Constitution provides that no person shall offer any property, gift or gratification as an inducement for the granting of any favour to a public officer in his or her official capacity. ${ }^{75}$ This section seems to be in conflict with section 6(3) of the Constitution. Federal and state public service officials are required to conform to and observe the provisions of the Code of Conduct Bureau and Tribunal Act and shun corruption and the abuse of office. ${ }^{76}$ The Constitution also provides that a public officer should abstain from putting himself in a position where his or her personal interests conflict with his or her official duties in order to forestall corrupt practices. ${ }^{77}$ Part I, section 2(b) to the Fifth Schedule to the Constitution prohibits a public officer from engaging or participating in the management or running of any private business, profession, or trade, except where he or she is employed on a part-time basis or doing farming. ${ }^{78}$ Similarly, the President, State Governors and their Deputies are prohibited by the Constitution from being employed in the service of foreign companies and enterprises after leaving office. ${ }^{79}$ The law also prohibits the President, the Vice President, State Governors, Deputy Governors and other public officers from accepting any benefit of whatever nature from any companies, contractors, businessmen or their nominees or agents. ${ }^{80}$ Although the Constitution does not give any reason for the provisions stated above, it is submitted that collecting gifts or benefits from contractors could be unethical and corrupt. Despite all the provisions stated above meant to prevent public officials from engaging in corrupt practices, section 308 of the Constitution protects some public officials such as the President of Nigeria, his deputy and others from any civil proceedings or criminal prosecution relating to acts or the practice of corruption or any other offence.

However, in order to check corrupt practices by public officers generally, the CCB and Code of Conduct Tribunal was established. This Tribunal was set up by the federal government under the Code of Conduct Bureau and

74 Section 15 of the Code of Conduct Bureau and Tribunal Act; $\mathrm{s} 11$ of Part I of the Fifth Schedule to the Constitution.

75 Sections 8, 9 and 10 of Part 1 of the Fifth Schedule to the Constitution.

76 Sections 172 and 209 of the Constitution; Akande Introduction to the Constitution 280.

77 Section 1 of Part I of the Fifth Schedule to the Constitution.

78 Also see Okoye $v$ Santilli (1994) 4 NWLR (pt 338) 289 para 4; Nwankwo v Nwankwo (1995) 5 NWLR (pt 394) 153 para 53.

79 Paragraph 5 of Part I of the Fifth Schedule to the Constitution.

80 Section 11 (b) of the Code of Conduct Bureau and Tribunal Act; para 7 of Part I of the Fifth Schedule to the Constitution. 
Tribunal Act. ${ }^{81}$ The Code of Conduct Tribunal is a quasi-judicial body established by the Code of Conduct Bureau and Tribunal Act, it has exclusive and original jurisdiction to try public officers on charges of corruption and related cases. ${ }^{82}$ The CCB was established as a federal executive body under section 153(1)(a) of the Constitution. It has the power to receive declarations by public officers made under paragraph 12 of Part I of the Fifth Schedule to the Constitution and examine the declarations in accordance with the requirements of any applicable law and retain custody of such declarations. It also has the power to make the declared assets form available for inspection by any citizen of Nigeria on such terms and conditions as the National Assembly may prescribe. ${ }^{83}$ However, the National Assembly is yet to enact a law enabling the public to access the declared asset forms of public officers in the custody of the CCB.

The CCB also has the power to investigate any lodged complaints and where appropriate to refer such matters to the Code of Conduct Tribunal. ${ }^{84}$ Thus, a false declaration of assets by a public officer in Nigeria is an offence. The Constitution provides that where the Code of Conduct Tribunal finds a public officer guilty of contravening any relevant provisions, he or she will incur penalties stipulated in the Fifth Schedule to the Constitution. ${ }^{85}$ The Code of Conduct Bureau and Tribunal Act may impose penalties such as the vacation of office in any legislative house, disqualification from membership of a legislative house, disqualification from holding any public office for a period not exceeding ten years, and the seizure and forfeiture to the state of any property acquired through corruption. ${ }^{86}$ However, section 18(3) of the Code of Conduct Bureau and Tribunal Act stipulates that these sanctions are without prejudice to the penalties that may be imposed by any law where the conduct is also a criminal offence. Public officers often register their illicit assets in the names of their spouses and children in an attempt to conceal such assets from the prying eyes of the law. ${ }^{87}$ Thus, public officers are required to declare also the income, assets and liabilities of their spouses and unmarried children. ${ }^{88}$ The law should clarify whether

\footnotetext{
Code of Conduct Bureau and Tribunal Act Chapter C15 LFN 2010.

Section 20 of the Code of Conduct Bureau and Tribunal Act.

Section 3(c) of Part I of the Third Schedule to the Constitution.

Sections 20 to 25 of the Code of Conduct Bureau and Tribunal Act.

Section 18(1) of Part 1 of the Fifth Schedule to the Constitution.

Paragraph 18(2)(c) of Part I of the Fifth Schedule to the Constitution.

OECD Asset Declarations for Public Officials 14.

88 Paragraph 11(1)(b) of Part I of the Fifth Schedule to the Constitution; see also OECD Asset Declarations for Public Officials 14.
} 
the definition of children in this context includes step-children, adopted children and children born out of wedlock.

Similarly, specific sections of the Federal Inland Revenue Services (Establishment) Act, 2007 provides wide and extensive powers to Federal Inland Revenue Services to check corruption and tax evasion. The Federal Inland Revenue Services may demand information relating to tax from a third party including a bank ${ }^{89}$ and the names and addresses of new customers, including those with a deposit of 10 million Naira and above currently standing to their credit. ${ }^{90}$ It may compel a third party such as a bank to provide information or produce documents specified in a written notice in order to ascertain the taxpayer's financial position, and the taxpayer is not privy to the request or the information given. ${ }^{91}$

Similarly, the Economic and Financial Crime Commission Act allows the EFCC to cause investigations to be conducted into the properties of any person if it appears to the commission that the person's lifestyle and the extent of the person's properties are not justified by his source of income. ${ }^{92}$ Further, the Nigeria Police (Establishment) Act, 2020 and the Criminal Procedure Act, $2004^{93}$ provide for the power of the police to act on a reasonable suspicion and make an arrest without a warrant. Likewise, under the Advance Fee Fraud and Related Offences Act, $2006^{94}$ and the Economic and Financial Crime Commission Act, 2004, ${ }^{95}$ the possession of unexplained wealth is taken into consideration as corroborative evidence or testimony in fraud proceedings.

Despite the elaborate provisions in the Constitution and the relevant laws such as the Economic and Financial Crime Commission Act regarding the use of lifestyle audits to prevent corruption and tax evasion, these measures have so far failed to effectively combat corruption in Nigeria. The low rating given to Nigeria by Transparency International on the corruption index is a case in point. ${ }^{96}$ Nigeria attempted to comply with articles 5,6 and 7 of the African Union Convention on Preventing and Combating Corruption, 2003 by providing various legislative and enforcement mechanisms against

\footnotetext{
Section 28(2) of the Federal Inland Revenue Services (Establishment) Act 13 of 2007.

Section 28(1) of the Federal Inland Revenue Services (Establishment) Act 13 of 2007.

Section 27 of the Federal Inland Revenue Services (Establishment) Act 13 of 2007.

Section 7(1)(b) of the Economic and Financial Crime Commission Act.

Section 10 of the Criminal Procedure Act Chapter C42 LFN 2004.

Section 15 of the Advance Fee Fraud and Related Offences Act 14 of 2006.

Section 19(5) of the Economic and Financial Crime Commission Act.

Transparency International

https://www.transparency.org/files/content/pages/2019_CPI_Report_EN.pdf 3. 
corruption, but the selective application of the enforcement mechanisms falls short of the principles and access to information guidelines provided in articles 3 and 9 of the African Union Convention on Preventing and Combating Corruption, 2003.

\section{Challenges affecting the reliance on lifestyle audits to combat corruption and tax evasion in Nigeria}

The administration of lifestyle audits is affected by numerous challenges which have essentially made it a less effective method of combating corruption and tax evasion in Nigeria. The immunity clause in section 308 of the Constitution grants immunity from criminal and civil prosecution or proceedings to the president, governors and their deputies of any criminal or civil offence committed whilst in office. ${ }^{97}$ This immunity provision was meant to allow the incumbent office holders to focus on governance and prevent them from being distracted by litigation. ${ }^{98}$ However, the immunity provision is counterproductive because these public officers use it as a shield to amass wealth through corrupt practices in Nigeria. ${ }^{99}$ For instance, most former state governors have had accusations of corruption levelled against them. ${ }^{100}$ However, anti-corruption commissions such as the EFCC, the Independent Corrupt Practices Commission and the CCB cannot prosecute or try the president, vice president, state governors and deputy governors while in office because they enjoy immunity under the Constitution. Moreover, due to the federal system of government in Nigeria there are inter-jurisdictional conflicts, and sometimes the state governments and their agencies refuse to cooperate with federal agencies in fighting

97 See the cases of Federal Government of Nigeria v Atiku Abubakar (unreported) case number CCT/NC/ABJ/06 of June 2006; Attorney-General of the Federation v Alhaji Atiku Abubakar (2007) 12 All FWLR (pt 389); Attorney-General of the Federation, Code of Conduct Bureau, and Code of Conduct Tribunal v Alh. Atiku Abubakar (2007) 8 NWLR (pt 1035) 155 para 2; Atiku Abubakar v Attorney-General of the Federation (2007) 3 NWLR (pt 1022) 546, 648 para 4. The court held in the above cases that charges of corruption cannot be brought against the Vice President of Nigeria irrespective of the existence of incontrovertible evidence.

98 Mowoe Constitutional Law in Nigeria 165-169.

99 There are, however, a few exceptions to the immunity clause as decided in the case of Fawehinmi v IGP (2002) 5 SC (pt 1) 63 81-82 where it was held that while a governor of a state cannot be prosecuted while in office, he could be investigated by the security agencies for an alleged crime. Another exception is that state governors are not immune from civil proceedings in respect of election petitions as decided in Alliance for Democracy v Fayose (2004) All FWLR (pt 218) 951 956-960.

100 See FRN v J Tevor Nyame (unreported) case number FCT/HC/CR/82/07 of July 2007; FRN v Joshua Dariye (unreported) case number FCT/HC/CR/81/07 of July 2007; Yakubu v FRN (2009) 14 NWLR (pt 1160) 151; Anwalu v FRN (2018) 8 NWLR (pt 1620) 107; Dasuki v FRN (2018) 10 NWLR (pt 1627) 320 para 5. 
corruption, even in conducting lifestyle audits. For instance, in AttorneyGeneral of Ondo State $v$ Attorney-General of the Federation ${ }^{101}$ the Ondo State government refused to cooperate with the Independent Corrupt Practices Commission in the prosecution of some of its officials who were charged with corruption by the Independent Corrupt Practices Commission. The Ondo State government averred that the Corrupt Practices Act ${ }^{102}$ was unconstitutional. The Supreme Court decided that it was the policy of the three tiers of government to eradicate corruption under the Constitution. ${ }^{103}$ The Supreme Court further held that the power to prohibit corrupt practices is concurrent and can be exercised by the federal and state governments. ${ }^{104}$

Related to this is the abuse of the power of nolle prosequi by the AttorneyGeneral of the Federation under section 174 of the Constitution for political purpose. ${ }^{105}$ For instance, in EFCC v Danjuma Goje, ${ }^{106}$ the defendant, the former governor of Gombe State, had twenty-one charges of corruption against him for embezzling funds totalling $\$ 25$ billion, but the AttorneyGeneral of the Federation took over the prosecution of the case and promptly withdrew the charges. They were dropped after the defendant withdrew from contesting the senate presidency in favour of president Buhari's preferred candidate. ${ }^{107}$ Similarly, in FRN $v$ Bola Tinubu ${ }^{108}$ the former governor of Lagos State was charged for making a false asset declaration and for maintaining multiple foreign accounts, contrary to the provisions of the Constitution and the Code of Conduct Bureau and Tribunal Act. ${ }^{109}$ The Code of Conduct Tribunal struck the case out on a technicality, and for political reasons the case was not appealed against by the federal government. ${ }^{110}$ Such political reasons included doing the bidding of the president and the ruling party at the federal level, or joining the ruling All

101 Attorney-General of Ondo State $v$ Attorney-General of the Federation (2002) 9 NWLR (pt 772) 222.

102 Corrupt Practices and Other Related Offences Act Chapter C31 LFN 2004.

103 Sections 15(5), 318(1), 49(2), 4(4)(b) and 4(7)(c) of the Constitution.

104 Attorney-General of Ondo State $v$ Attorney-General of the Federation (2002) 9 NWLR (pt 772) 222.

105 Section 174 of the Constitution.

106 Anon 2019 https://punchng.com/alleged-n25bn-fraud-efcc-withdraws-from-gojescase/ 12.

107 Punch Editorial Board 2020 https://punchng.com/resolving-high-profile-corruptioncases/.

108 FRN v Bola Ahmed Tinubu (unreported) case number CCT/ABJ/01/11 of January 2011; also see FRN $v$ Emil Lemke Inyang (unreported) case number CCT/ABJ/02/2012 of January 2012.

109 Paragraph 3 of Part I of the Fifth Schedule to the Constitution; section 7 of the Code of Conduct Bureau and Tribunal Act.

110 Ndujihe, Nnochiri and Ajayi 2016 https://www.vanguardngr.com/2016/03/allegedfalse-declaration-cct-declines-quash--charge-saraki/ 15. 
Progressive Congress. Some public officers make anticipatory assets declarations, while others under-declare their assets. ${ }^{111}$ Public officers that make anticipatory assets declaration are usually hitherto private citizens who inflate their asset profile so that when they leave office their assets will seem be within the bounds of legitimate income. However, career public servants usually under-declare their assets and keep some assets in the name of others to avoid being charged with tax evasion and/or corruption.

The ineffective verification of assets declarations by the CCB is another challenge because of inadequate technological inputs. ${ }^{112}$ The CCB does not use technology to conduct lifestyle audits in Nigeria. Millions of Naira are transferred in physical cash in Nigeria daily. ${ }^{113}$ Such payments are often difficult to trace. ${ }^{114}$ Although there are provisions for electronic transfers and payment they are still bedevilled by serious challenges such as deficiencies in infrastructure, reliability and platform security. ${ }^{115}$ Increasing connectivity and the increased provision of efficient technological innovation may deliver payments through secure, transparent and convenient digital channels, thereby reducing corruption and tax evasion in Nigeria. ${ }^{116}$ Technological development has effectively altered the way in which financial systems operate. It has made banking and payment for commercial transactions fast, and has facilitated unrestricted cross-border electronic money transfers. ${ }^{117}$ But advanced technology such as electronic money transfer has also made money laundering easier, so Nigerian lifestyle auditors must be technologically savvy to be able to perform their function effectively. However, it is relatively easier to trace illegal transactions done electronically than those facilitated by the transfer of physical cash. The Auditor-General of the Nigerian Federation has also identified the inadequate use of appropriate and modern technology as one of the challenges facing audit institutions. The Auditor-General advocated the automation of the Conduct Bureau, the Code of Conduct Tribunal and the Auditor-General's office. ${ }^{118}$ The authors submit that asset declaration and verification procedure is still done manually in Nigeria. The verification of

\footnotetext{
See Dr Olubukola Abubakar Saraki v FRN (2016) 6 All FWLR (pt 836) 59 paras 1-3.

Waziri Corruption and Governance Challenge 6.

Okifo and Igbunu 2015 Journal of Education and Practice 59-60.

114 Wald $2018 \mathrm{https}: / /$ www.weforum.org/agenda/2018/04/governments-join-digitalpayment-revolution-fight-corruption/ 1-2.

115 Okifo and Igbunu 2015 Journal of Education and Practice 59-60.

116 Wald 2018 https://www.weforum.org/agenda/2018/04/governments-join-digitalpayment-revolution-fight-corruption/ 1-2.

117 Adetunji Comparative Analysis of the Control of Financial Crime 67.

118 Ayine 2019 https://www.oaugf.ng/news1/258-audit-as-an-instrument-for-fightingcorruption.
} 
the assets of the millions of public servants is impossible without the employment of sophisticated technology. In addition, the CCB and the Auditor-General staff have so far failed to provide adequate training and skills in modern forensic auditing techniques. Thus, the CCB and the Auditor-General staff are ill-equipped to detect and gather sufficient evidence regarding corruption and to effectively carry out their oversight duties and risk-based audits. ${ }^{119}$

In addition, the effectiveness of the assets declaration regime in Nigeria is hampered by the fact that the human resources available to the CCB and the Code of Conduct Tribunal are grossly inadequately equipped and resourced. ${ }^{120}$ Moreover, the CCB and the Code of Conduct Tribunal are not completely independent institutions since they are controlled by the executive arm of government and are thus susceptible to its whims. ${ }^{121}$ It seems as if the selection of the cases prosecuted by the CCB and the Code of Conduct Tribunal is motivated by political interest rather than by a genuine interest in combating corruption, because corruption-related cases are discontinued once the accused become more politically compliant to the ruling political party. ${ }^{122}$

The lifestyle audit regime in Nigeria is also bedevilled by another weakness, in that it makes no provision for the participation of the public and civil society organisations. The Constitution provides that the CCB should make assets declared by public officers available subject to such terms and conditions as the National Assembly may prescribe. ${ }^{123}$ Many Nigerians and civil society organisations have made requests to the CCB to make available the assets declarations by public officers, especially political office holders, for inspection, without success. ${ }^{124}$ The CCB has refused all such requests. The CCB's refusal is based on the fact that the National Assembly has not passed a law enabling the public to access such assets declarations. For instance, in the Incorporated Trustees of Media Rights

\footnotetext{
119 Akhidime and Izedonmi 2012 USV Ann Econ Publ Adm 188; Erero and Oladoyin "Tackling the Corruption Epidemic in Nigeria" 284.

120 According to the Chairman of the CCB, there are more than four million Nigerians working in the public service, all of whom are required to declare their assets. See Umar 2012 http://allafrica.com/stories/201209290446.html 4; African Tax Administration Forum 2017 https://www.ataftax.org/en/products-services/africantaxoutlook.

121 Ayinde Assessment of Assets Declaration by Public Officers 5.

122 Ayinde Assessment of Assets Declaration by Public Officers 5.

123 Paragraph 3(c) of Part I of the Third Schedule to the Constitution.

124 Lawal 2009 AHRLJ 243-255.
} 
Agenda $v$ the Code of Conduct Bureau, ${ }^{125}$ Media Rights Agenda (MRA) requested access to the assets declaration forms of certain public officers, but the CCB refused to grant their request. Subsequently the MRA instituted an action in the federal High Court but the case was dismissed on the ground that there was no law in place yet that mandates the CCB to allow the public to access the asset declaration of public servants. The CCB's refusal to allow the full participation of the media and civil society is a violation of Article 12 of the African Union Convention on Preventing and Combating Corruption, 2003.

\section{The effect of the corona virus (COVID-19) pandemic on corruption and tax evasion in Nigeria}

The COVID-19 virus that is ravaging the whole world is having a negative effect on the Nigerian economy, which depends on oil exports for financing a substantial part of its budget. ${ }^{126}$ The federal government of Nigeria decided to adopt some policies in the bid to boost internally generated revenue in the midst of dwindling foreign earnings from crude oil. However, such policies have created further financial burden for the ordinary people. ${ }^{127}$ The federal government increased certain taxes, such as stamp duty, despite the obvious fall in the income of most households and the pervasive job loss in Nigeria due to the COVID-19 pandemic. ${ }^{128}$ The government increased the rate of Value Added Tax (VAT) from 5 per cent to 7.5 per cent, resuscitated the stamp duty charge and introduced stamp

125 Incorporated Trustees of Media Rights Agenda $v$ Code of Conduct Bureau (unreported) case number FHC/ABJ/CS/171/2017 of 29 June 2017. Also see Media Rights Agenda v Nigeria (Communication No 224/98) [2000] ACHPR 24 (6 November 2000); Incorporated Trustees of Media Rights Agenda v House of Representatives, The Clerk of House of Representatives, AG of the Federation (unreported) case number FHC/CS/648/2014 of 20 September 2014; Incorporated Trustees of Media Rights Agenda and the Incorporated Trustees of Public and Private Development $v$ The Nigerian Civil Aviation Authority and the Attorney General of The Federation (unreported) case number $\mathrm{FHC/L/CS/1689/2013} \mathrm{of} 10$ July 2013; Incorporated Trustees of Media Rights Agenda v Nigerian Police Force, IGP and the AG of the Federation (unreported) case number FHC/ABJ/CS/221/16 of 3 November 2016; Incorporated Trustees of Media Rights Agenda v Ojodu Local Council Development Area and the $A G$ of the Federation (unreported) case number ID/1129MJR/2016 of 10 December 2016.

126 Ozili 2020 Journal of Financial Crime 531-539; Nwoba and Abah IOSR-JHSS 86-88; Nwoba, Nwonu and Agbaeze 2017 JPID 75.

127 Raffaele 2020 https://www.voanews.com/episode/nigerians-protest-increaseelectricity-and-fuel-prices-amid-coronavirus-pandemic-4421451 1-2.

128 Raffaele 2020 https://www.voanews.com/episode/nigerians-protest-increaseelectricity-and-fuel-prices-amid-coronavirus-pandemic-4421451 1-2. 
duty on house rents and certificate of occupancy transactions. ${ }^{129}$ The price of petroleum products and electricity tariffs were increased by the federal government agencies, which claimed that the government was withdrawing from subsidising these products. These policies have created resentment against the federal Nigerian government and the ENDSARS (End Special Anti-Robbery Squad) protests, which were online and street protests against police brutality and corruption generally, were a product of the enduring hardship which was accentuated by the COVID-19 epidemic and the government's hard-hearted response. ${ }^{130}$ The remote and immediate causes of the ENDSARS protests in Nigeria's major towns are not unconnected with endemic corruption and extra judicial killings by the Nigeria Police Force and the negative attitude of the Nigerian political elites. ${ }^{131}$ In Federal Government of Nigeria v Tafa Balogun ${ }^{132}$ the former Inspector General of Police was indicted under the Money Laundering Act ${ }^{133}$ on a 56-count charge of money laundering and embezzlement of about N17 billion (about US\$132 million). Upon his guilty plea he was sentenced to a 6-month term of imprisonment. This short jail sentence is not robust enough for deterrence purposes. The pervading corruption in Nigeria is beyond alarming and has entered the fatal stage. ${ }^{134}$ According to the World Bank, as cited in Achebe's book, over 40 billion US dollars has been stolen from the Nigerian economy in the past four decades. ${ }^{135}$ Furthermore, it must be noted that there was mass looting of the COVID-19 palliatives during the ENDSARS protests due to the selfish policies of the Nigerian federal government. ${ }^{136}$ For instance, the palliatives against COVID-19 donated by the Nigerian Private Sector Coalition meant for distribution to the vulnerable and the poor during the lockdown were kept in warehouses and not distributed for many months. ${ }^{137}$ The various state governments of Nigeria hoarded the palliatives. They probably intended to use the COVID-19

129 Njoku et al 2020 https://guardian.ng/news/hard-times-in-buharis-change-regime/ 1416.

130 Raffaele 2020 https://www.voanews.com/episode/nigerians-protest-increaseelectricity-and-fuel-prices-amid-coronavirus-pandemic-4421451 1-3.

131 Zumve 2020 IJSSHR 135-136; Uwazuruike 2020 Harv Hum Rts J 1-7.

132 Federal Government of Nigeria $v$ Tafa Balogun (unreported) case number $\mathrm{FHC/AB/CR/14/2005} \mathrm{of} \mathrm{June} 2005$.

133 Section 14 of the Money Laundering (Prohibition) Act 7 of 2011.

134 Achebe There was a Country 249

135 Achebe There was a Country 249.

136 Uwazuruike 2020 Harv Hum Rts J 1-7.

137 Ezeibe 2020 Global Public Health 1758-1766; Jayaram et al 2020 https://www.mckinsey.com/featured-insights/middle-east-and-africa/tackling-covid19-in-africa\# 12; Beratazegui $2020 \mathrm{https} / / / \mathrm{www}$.transparency.org/en/blog/the-imfcovid-19-and-anti-corruption-the-story-so-far; Ndegwa 2020 https://allafrica.com/ stories/202009070230.html 12. 
palliatives for political purposes by distributing them during the upcoming local government elections. The manner in which the monetary and material palliatives was handled by the government lacked transparency. ${ }^{138}$ This gave rise to COVID-19-related corruption and tax evasion in Nigeria.

\section{Recommendations}

The policies and legal framework for lifestyle audits in Nigeria need to be reformed. Consequently, section 308 of the Constitution should be amended to discourage public officials from engaging in corruption with impunity. This would serve as a deterrent to public officers from engaging in corrupt practices due to their fear of public prosecution. Similarly, part 1, section 6(3) of the Constitution, which allows a public officer to accept personal gifts or benefits from friends and relatives within the context of cultural practice, should be expunged from the Constitution because it encourages the giving and acceptance of bribes. For instance, a retired Nigerian public officer claimed that a sum of 9.8 million dollars recovered from his house was the accumulation of gifts received from friends and relatives. ${ }^{139}$

The bodies charged with lifestyle audits such as the CCB, Code of Conduct Tribunal and the Auditor-General's office should be well resourced and provided with digitalised facilities and modern technology in order to cope with the asset declaration forms of millions of public servants, which cannot be processed under the current era of manual system. In addition, there is a need to equip the staff of the CCB, the Code of Conduct Tribunal, the Nigeria Police Force and the Auditor-General's office with intensive training and technological skills. Enabling laws such as the Code of Conduct Bureau and Tribunal Act should be amended in order to grant the public access to the asset declaration forms of public officials in order to assess the accuracy and completeness of such forms. The salary of the staff of the agencies responsible for lifestyle audits must be increased and adjusted to inflation, especially under the COVID-19 pandemic-induced recession, so that the staff members do not themselves engage in corrupt activities. In addition, the increase in the tax rate, electricity tariff and petroleum products by the federal government of Nigeria should be reversed since most people are struggling to get jobs and decent incomes under the COVID-19 pandemic. Lastly, the institutions charged with the task of fighting corruption should be

\footnotetext{
138 Eranga 2020 IJMA 220-222.

139 Eranga 2020 IJMA 220-222; Ndegwa 2020 https://allafrica.com/ stories/202009070230.html 12.
} 
restructured, adequately funded and strengthened to ensure their independence and the proper execution of their duties. The need for the restructuring of the anti-corruption institutions is based on the fact that they are sometimes under-resourced and biased when executing their functions. Specialised anti-corruption agencies such as the Independent Corrupt Practices Commission and the EFCC, the Special Anti-Fraud Unit of the Nigeria Police, the special anti-corruption units of the Bureau of Public Procurement (BPP), the Nigerian Extractive Industries Transparency Initiative (NEITI), the Public Complaints Commission, the Office of the Auditor-General of the Federation and the Technical Unit on Governance and Anti-Corruption Reforms should employ innovative technology to detect and curb corruption. It is noteworthy that a new bill to create another anticorruption agency to be known as the Proceeds of Crime Recovery and Management Agency is before the National Assembly. It is submitted that the creation of an additional anti-corruption agency in Nigeria is superfluous and could lead to jurisdictional and other overlapping challenges. Instead, the Independent Corrupt Practices Commission and the EFCC should be merged in order to harmonise their activities and adequately fund operations optimally.

\section{Conclusion}

Conducting lifestyle audits of public officials is acknowledged as a measure that could aid in promoting accountability, transparency and integrity in the conduct of government officials and public officials in Nigeria. ${ }^{140}$ This article has analysed the adequacy of the relevant lifestyle audits laws and their enforcement to curb corruption and tax evasion in Nigeria. For instance, it has been noted that laws such as the Corrupt Practices and Other Related Offences Act, the Code of Conduct Bureau and Tribunal Act and the Economic and Financial Crime Commission Act are flawed and inconsistently enforced, thus being unable to combat corruption. For instance, the regulatory bodies responsible for lifestyle audits do not use technological measures to cope with the large number of public officials required by the CCB to declare their assets and verify such assets. Consequently, it is imperative that the lifestyle audit regime in Nigeria should be automated. Moreover, the anti-corruption agencies such as the EFCC, the CCB, the Nigeria Police and the tax agencies such as the Federal Inland Revenue Service should be well resourced and work together cooperatively to curb corruption. This approach could enhance the combating of corruption and tax evasion. It is hoped that the relevant authorities will

140 Hatchard Combating Corruption 40. 
utilise the aforementioned recommendations to effectively curb corruption and tax evasion in Nigeria through the administration of lifestyle audits to public officials.

\section{Bibliography}

\section{Literature}

Abiloro, Olawole and Adeniran 2019 IJARAFMS

Abiloro TO, Olawole A and Adeniran TE "Corruption, Income Inequality, and Economic Development in Nigeria" 2019 IJARAFMS 304-319

Abu and Staniewski 2019 Economic Research

Abu N and Staniewski MW "Determinants of corruption in Nigeria: Evidence from Various Estimation Techniques" 2019 Economic Research 3058-3082

Achebe There was a Country

Achebe C There was a Country: A Personal History of Biafra (Penguin Books London 2012)

Adetunji Comparative Analysis of the Control of Financial Crime Adetunji AJ A Comparative Analysis of the Control of Financial Crime from the Perspective of the UK, the USA and Nigeria (PhD-thesis University of London 2016)

Ajaz and Ahmad 2010 Pak Dev Rev

Ajaz $T$ and Ahmad E "The Effect of Corruption and Governance on Tax Revenues" 2010 Pak Dev Rev 405-417

Akande Introduction to the Constitution

Akande J Introduction to the Constitution of the Federal Republic of Nigeria (MIJ Publishers Lagos 2000)

Akhidime and Izedonmi 2012 USV Ann Econ Publ Adm

Akhidime AE and Izedonmi IO "Challenges of Supreme Audit Institutions: Perspective of Auditor-General of Nigeria" 2012 USV Ann Econ Publ Adm 183-189

Alege et al 2014 GJISS

Alege SO et al "Effects of Corruption on Economic Development in Nigeria" GJISS 209-215 
Alm and Liu 2017 eJournal of Tax Research

Alm J and Liu Y "Corruption, Taxation and Tax Evasion" 2017 eJournal of Tax Research 161-189

Alm, Martinez-Vazquez and McClellan $2016 \mathrm{~J}$ Ec Behav \& Org

Alm J, Martinez-Vazquez $\mathrm{J}$ and McClellan $\mathrm{C}$ "Corruption and Firm Tax Evasion" 2016 J Ec Behav \& Org 146-163

Aluko "Corruption in Nigeria"

Aluko YA "Corruption in Nigeria: Concept and Dimensions" in Enweremadu DU and Okafor EE (eds) Anti-Corruption Reforms in Nigeria since 1999: Issues, Challenges and the Way Forward (French Institute for Research in Africa Ibadan 2009) 1-20

Amaefule and Umeaka 2016 IJIDPS

Amaefule LI and Umeaka EC "Combating Economic and Financial Crimes by the Anti-Graft Agencies in Nigeria: Implications on the Nation's Economic Growth and Development" 2016 IJIDPS 8-33

Ambar $2015 \mathrm{JEF}$

Ambar R "Corruption, Inequality and Economic Growth" 2015 JEF 106-111

Andvig Corruption in Sub-Saharan Africa

Andvig JC Corruption in Sub-Saharan Africa and Its Sources of Evidence (Norwegian Institute of International Affairs Oslo 2008)

Ayinde Assessment of Assets Declaration by Public Officers

Ayinde DJ An Assessment of Assets Declaration by Public Officers as an Anti-Corruption Measure in Nigeria (LLM-dissertation University of the Western Cape 2019)

Baum et al 2017 eJournal of Tax Research

Baum A et al "Corruption, Taxes and Compliance" 2017 eJournal of Tax Research 190-216

Besley and Persson 2014 JEP

Besley $T$ and Persson T "Why Do Developing Countries Tax So Little?" 2014 JEP 99-120

Brooks et al Preventing Corruption

Brooks G et al Preventing Corruption: Investigation, Enforcement and Governance (Palgrave Macmillan London 2013) 
Christians 2017 JOTA

Christians A "Distinguishing Tax Avoidance and Evasion: Why and How?" 2017 JOTA 5-21

Coenen Expert Fraud Investigation

Coenen T Expert Fraud Investigation (Wiley Hoboken 2009)

Coenen Expert Fraud Investigation: Step-by-Step Guide

Coenen TL Expert Fraud Investigation: A Step-by-Step Guide (Wiley Hoboken 2012)

Croome and Croome Street Smart Taxpayers

Croome B and Croome J Street Smart Taxpayers: A Practical Guide to your Rights in South Africa (Juta Cape Town 2017)

D'Arcy and Cornell 2016 African Affairs

D'Arcy M and Cornell A "Devolution and Corruption in Kenya: Everyone's Turn to Eat?" 2016 African Affairs 246-273

Egobueze and lyalla 2020 IJSSH

Egobueze A and lyalla IA "The Auditor-General for Local Governments' and Accountability in Local Government Administration in Rivers State 20072018" 2020 IJSSH 7-13

Eranga 2020 IJMA

Eranga IO "COVID-19 Pandemic in Nigeria: Palliative Measures and the Politics of Vulnerability" 2020 IJMA 220-222

Erero and Oladoyin "Tackling the Corruption Epidemic in Nigeria" Erero $\mathrm{J}$ and Oladoyin $\mathrm{T}$ "Tackling the Corruption Epidemic in Nigeria" in Ronald K and Chikulo B (eds) Corruption and Development in Africa: Lessons from Country Case-Studies (Macmillan Basingstoke 2000) 280287

Evans 2017 eJournal of Tax Research

Evans C "Editorial: The Complex and Critical Relationship between Tax and Corruption" 2017 eJournal of Tax Research 140-143

Ezeibe 2020 Global Public Health

Ezeibe CC "Political Distrust and the Spread of COVID-19 in Nigeria" 2020 Global Public Health 1753-1766 
Fjeldstad and Moore 2009 JMAS

Fjeldstad $\mathrm{O}$ and Moore $\mathrm{M}$ "Revenue Authorities and Public Authority in SubSaharan Africa" 2009 JMAS 1-18

Hatchard Combating Corruption

Hatchard J Combating Corruption: Legal Approach to Supporting Good Governance and Integrity in Africa (Edward Elgar Cheltenham 2014)

Hoffmann and Patel Collective Action on Corruption in Nigeria Hoffmann LK and Patel RN Collective Action on Corruption in Nigeria: A Social Norms Approach to Connecting Society and Institutions (The Royal Institute of International Affairs London 2017)

ljewereme 2013 Quarterly Journal of Administration

ljewereme OB "An Examination of Anti-Corruption Crusades in Nigeria: Issues and Challenges" 2013 Quarterly Journal of Administration 108-127

ljewereme 2015 SAGE Open

ljewereme $O B$ "Anatomy of Corruption in the Nigerian Public Sector: Theoretical Perspectives and Some Empirical Explanations" 2015 SAGE Open 1-16

\section{IMF Corruption}

International Monetary Fund Fiscal Affairs and Legal Departments Corruption: Costs and Mitigating Strategies (International Monetary Fund Washington DC 2016)

Jack-Osimiri and Kokpan "Fraud and Corruption in Nigerian Taxation" Jack-Osimiri U and Kokpan BS "Fraud and Corruption in Nigerian Taxation: Eradication or Control?" in Ignatius Ajuru University of Education Repositioning Development Agenda in Africa Conference (14-17 August 2016 Port Harcourt) 1-15

Jayawickrama, Pope and Stolpe 2001 Forum on Crime and Society Jayawickrama N, Pope J and Stolpe O "Legal Provisions to Facilitate the Gathering of Evidence in Corruption Cases: Easing the Burden of Proof " 2001 Forum on Crime and Society 23-32

Kelly Corruption in Africa

Kelly RM Corruption in Africa: Cultural, Economic and Political Factors which Impact Corruption and Potential Solutions (MA-dissertation State University of New Jersey 2014) 
Karlsson and Matthiasson 2015 Nordic Tax Journal

Karlsson $\mathrm{J}$ and Matthiasson $\mathrm{T}$ "Tax Evasion, Tax Avoidance and the Influence of Special Interest Groups: Taxation in Iceland from 1930 to the Present" 2015 Nordic Tax Journal 1-17

Lawal 2009 AHRLJ

Lawal IB "Public Declaration of Assets in Nigeria: Conflict or Synergy between Law and Morality?" 2009 AHRLJ 224-261

Mahesh "Corruption in Tax Administration"

Mahesh P "Corruption in Tax Administration" in Shah A (ed) Performance Accountability and Combating Corruption (World Bank Washington DC 2007) 285-302

Mowoe Constitutional Law in Nigeria

Mowoe KM Constitutional Law in Nigeria (Malthouse Law Books Lagos 2008)

Munjeyi and Mujuru 2018 IJIRSET

Munjeyi $E$ and Mujuru $S$ "Is it Worth Investing in 'Lifestyle Audit' in Zimbabwe?" 2018 IJIRSET 8632-8638

Nwoba and Abah 2017 IOSR-JHSS

Nwoba MOE and Abah EO "Impact of Crude Oil Revenue (COR) on Economic Growth in Nigeria (1960-2010)" 2017 IOSR-JHSS 85-99

Nwoba, Nwonu and Agbaeze 2017 JPID

Nwoba MOE, Nwonu C and Agbaeze EK "Impact of Fallen Oil Prices on the Nigeria Economy" 2017 JPID 75-82

Odeku 2019 JLERI

Odeku OK "Unmasking Life-Style Audit as a Proactive Mechanism to Root out Corruption: The Case of South Africa" 2019 JLERI 1-13

OECD Asset Declarations for Public Officials

Organisation for Economic Co-operation and Development Asset Declarations for Public Officials: A Tool to Prevent Corruption (OECD Paris 2011)

Ogbu 2008 Ann Surv Int'l \& Comp L Ogbu ON "Combating Corruption in Nigeria: A Critical Appraisal of the Laws, Institutions, and the Political Will" 2008 Ann Surv Int'l \& Comp L 99-149 
Ojukwu Discovering the Police

Ojukwu ECS Discovering the Police $2^{\text {nd }}$ ed (Kraft Book Ibadan 2016)

Okifo and Igbunu 2015 Journal of Education and Practice

Okifo J and Igbunu R "Electronic Payment System in Nigeria: Its Economic Benefits and Challenges" 2015 Journal of Education and Practice 56-62

Okolo and Raymond 2014 GJHSS

Okolo PO and Raymond AO "Corruption in Nigeria: The Possible Way Out" 2014 GJHSS 30-38

Onuigbo and Eme 2015 AJBMR

Onuigbo RA and Eme Ol "Corruption and Administration in Nigeria: The Character of the State Thesis" 2015 AJBMR 17-36

Otusanya $2010 \mathrm{CPA}$

Otusanya OJ "The Role of Multinational Companies in Tax Evasion and Tax Avoidance: The Case of Nigeria" 2010 CPA 316-322

Ozili 2020 Journal of Financial Crime

Ozili PK "Tax Evasion and Financial Instability" 2020 Journal of Financial Crime 531-539

Rose-Ackerman 2002 Focus on Crime and Society

Rose-Ackerman S "Corruption and the Criminal Law" 2002 Focus on Crime and Society 3-22

Rosid, Evans and Tran-Nam 2016 eJournal of Tax Research

Rosid A, Evans C and Tran-Nam B "Do Perceptions of Corruption Influence Personal Income Taxpayer Reporting Behaviour? Evidence from Indonesia" 2016 eJournal of Tax Research 387-421

Schlenther 2017 eJournal of Tax Research

Schlenther B "The Impact of Corruption on Tax Revenues, Tax Compliance and Economic Development: Prevailing Trends and Mitigation Actions in Africa" 2017 eJournal of Tax Research 217-242

Slemrod 2007 JEP

Slemrod J "Cheating Ourselves: The Economics of Tax Evasion" 2007 JEP $25-48$

Tanzi 2017 eJournal of Tax Research

Tanzi V "Corruption, Complexity and Tax Evasion" 2017 eJournal of Tax Research 144-160 
Tanzi and Davoodi "Corruption, Public Investment, and Growth"

Tanzi V and Davoodi H "Corruption, Public Investment, and Growth" in Abed GT and Gupta S (eds) Governance, Corruption, and Economic Performance (International Monetary Fund Washington DC 2002) 280-299

Turner Money Laundering Prevention

Turner JE Money Laundering Prevention: Deterring, Detecting and Resolving Financial Fraud (Wiley Hoboken 2011)

Ugwu and Gordon 2018 JSC

Ugwu MO and Gordon M "Perceptions of Unrestricted Gift Giving and the Integrity of Public Servants in Nigeria" 2018 JSC 118-133

Uwazuruike 2020 Harv Hum Rts J

Uwazuruike A '\#EndSARS: The Movement against Police Brutality in Nigeria" 2020 Harv Hum Rts J 1-7

Van Rooyen Practitioner's Guide to Forensic Investigation

Van Rooyen H The Practitioner's Guide to Forensic Investigation in South Africa (Henmar Pretoria 2008)

Van Vuuren "South Africa: Democracy, Corruption and Conflict Management"

Van Vuuren H "South Africa: Democracy, Corruption and Conflict Management" in the Democracy Works Project Seminar at the Centre for Development and Enterprise (April 2013) 1-40

Vannucci 2009 Bulletin of Italian Politics

Vannucci A "The Controversial Legacy of 'Mani Pulite': A Critical Analysis of Italian Corruption and Anti-Corruption Policies" 2009 Bulletin of Italian Politics 233-264

Waziri Corruption and Governance Challenge

Waziri F Corruption and Governance Challenge (CLEEN Foundation Abuja 2010)

Zumve 2020 IJSSHR

Zumve IS "The Political Economy of the \#Endsars Protest in Nigeria: Opening the 'Black Box' of Police Brute-Force and Extrajudicial Executions" 2020 IJSSHR 132-139 


\section{Case law}

\section{England}

Nigeria v Santolina Investment Company [2007] EWHC 437 (Ch)

\section{Nigeria}

Alliance for Democracy v Fayose (2004) All FWLR (pt 218) 951

Anwalu v FRN (2018) 8 NWLR (pt 1620) 107

Atiku Abubakar v Attorney-General of the Federation (2007) 3 NWLR (pt 1022) 546

Attorney-General of Ondo State $v$ Attorney-General of the Federation (2002) 9 NWLR (pt 772) 222

Attorney-General of the Federation v Alhaji Atiku Abubakar (2007) 12 All FWLR (pt 389)

Attorney-General of the Federation, Code of Conduct Bureau, and Code of Conduct Tribunal v Alh Atiku Abubakar (2007) 8 NWLR (pt 1035) 155

Dasuki v FRN (2018) 10 NWLR (pt 1627) 320

Dr Olubukola Abubakar Saraki v FRN (2016) 6 All FWLR (pt 836) 59

Fawehinmi v IGP (2002) 5 SC (pt 1) 63

Federal Government of Nigeria v Atiku Abubakar (unreported) case number $\mathrm{CCT} / \mathrm{NC} / \mathrm{ABJ} / 06$ of June 2006

Federal Government of Nigeria v Tafa Balogun (unreported) case number $\mathrm{FHC} / \mathrm{AB} / \mathrm{CR} / 14 / 2005$ of June 2005

FRN v Bola Ahmed Tinubu (unreported) case number CCT/ABJ/01/11 of January 2011

FRN v Emil Lemke Inyang (unreported) case number CCT/ABJ/02/2012 of January 2012

FRN v J Tevor Nyame (unreported) case number FCT/HC/CR/82/07 of July 2007 
FRN $v$ Joshua Dariye (unreported) case number FCT/HC/CR/81/07 of July 2007

Incorporated Trustees of Media Rights Agenda and the Incorporated Trustees of Public and Private Development $v$ The Nigerian Civil Aviation Authority and the Attorney General of The Federation (unreported) case number $\mathrm{FHC/L/CS/1689/2013} \mathrm{of} 10$ July 2013

Incorporated Trustees of Media Rights Agenda v Code of Conduct Bureau (unreported) case number FHC/ABJ/CS/171/2017 of 29 June 2017

Incorporated Trustees of Media Rights Agenda v House of Representatives, The Clerk of House of Representatives, AG of the Federation (unreported) case number $\mathrm{FHC/CS/648/2014} \mathrm{of} 20$ September 2014

Incorporated Trustees of Media Rights Agenda v Nigerian Police Force, IGP and the $A G$ of the Federation (unreported) case number $\mathrm{FHC} / \mathrm{ABJ} / \mathrm{CS} / 221 / 16$ of 3 November 2016

Incorporated Trustees of Media Rights Agenda v Ojodu Local Council Development Area and the AG of the Federation (unreported) case number ID/1129MJR/2016 of 10 December 2016

Jim-Jaja v COP (2011) 2 NWLR (pt 1231) 375

Media Rights Agenda v Nigeria (Communication No 224/98) [2000] ACHPR 24 (6 November 2000)

Nwankwo v Nwankwo (1995) 5 NWLR (pt 394) 153

Okoye v Santilli (1994) 4 NWLR (pt 338) 289

Yakubu v FRN (2009) 14 NWLR (pt 1160) 151

Legislation

Advance Fee Fraud and Related Offences Act 14 of 2006

Code of Conduct Bureau and Tribunal Act Chapter C15 LFN 2010

Code of Conduct for Public Officers Chapter C15 LFN 2004

Constitution of the Federal Republic of Nigeria, 1999 Chapter C23 LFN 2004 
Corrupt Practices and Other Related Offences Act Chapter C31 LFN 2004 Criminal Procedure Act Chapter C42 LFN 2004

Economic and Financial Crimes Commission Act Chapter E1 LFN 2004

Failed Bank Tribunal Decree, 1996

Federal Inland Revenue Services (Establishment) Act 13 of 2007

Forfeiture of Assets Decree 53 of 1999

Money Laundering (Prohibition) Act 7 of 2011

Nigeria Police (Establishment) Act 4 of 2020

Nigerian National Petroleum Corporation Act Chapter N123 LFN 2004

Public Officers Protection Act Chapter P41 LFN 2004

Public Officer Investigation of Assets Decree 54 of 1976

International instruments

African Union Convention on Preventing and Combating Corruption (2003)

United Nations Convention against Corruption (2004)

Internet sources

African Tax Administration Forum 2017 https://www.ataftax.org/ en/products-services/african-taxoutlook

African Tax Administration Forum 2017 African Tax Outlook 2017 https://www.ataftax.org/en/products-services/african-taxoutlook accessed 15 November 2020

Alemika et al 2015 https://nigeria.actionaid.org/sites/nigeria/files/ pc_report_content.pdf

Alemika E et al 2015 Corruption and Poverty in Nigeria: A Report https://nigeria.

https://nigeria.actionaid.org/sites/nigeria/files/pc_report_content.pdf accessed 1 December 2020 
Alm 2012 http://repec.tulane.edu/RePEc/pdf/tul1213.pdf

Alm J 2012 Measuring, Explaining and Controlling Tax Evasion: Lessons from Theory, Experiments and Field Studies http://repec.tulane.edu/RePEc/pdf/ tul1213.pdf accessed 12 November 2020

Anon 2019 https://punchng.com/alleged-n25bn-fraud-efcc-withdraws-fromgojes-case/

Anon 2019 Alleged N25bn Fraud: EFCC Withdraws from Goje's Case https://punchng.com/alleged-n25bn-fraud-efcc-withdraws-from-gojes-case/ accessed 25 November 2020

Ayine 2019 https://www.oaugf.ng/news1/258-audit-as-an-instrument-forfighting-corruption

Ayine AM 2019 Audit as an Instrument for Fighting Corruption https://www.oaugf.ng/news1/258-audit-as-an-instrument-for-fightingcorruption accessed 10 November 2020

Beratazegui $2020 \mathrm{https} / / / \mathrm{www}$.transparency.org/en/blog/the-imf-covid-19and-anti-corruption-the-story-so-far

Beratazegui ME 2020 The IMF, COVID-19 and Anti-Corruption: The Story so Far https://www.transparency.org/en/blog/the-imf-covid-19-and-anticorruption-the-story-so-far accessed 25 November 2020

Gaspar, Mauro and Medas 2019 https://www.weforum.org/agenda/2019/ 04/tackling-corruption-in-government/

Gaspar V, Mauro P and Medas P 2019 The True Cost of Corruption is Higher than You Might Realize https://www.weforum.org/agenda/2019/ 04/tackling-corruption-in-government/ accessed 25 November 2020

InvestorWords Date Unknown http://www.investorwords.com/10191/ lifestyle_audit.html

InvestorWords Date Unknown Lifestyle Audit http://www.investorwords. com/10191/lifestyle_audit.html accessed 10 November 2020

Jayaram et al 2020 https://www.mckinsey.com/featured-insights/middleeast-and-africa/tackling-covid-19-in-africa\#

Jayaram $\mathrm{K}$ et al 2020 Tackling COVID-19 in Africa https://www.mckinsey.com/featured-insights/middle-east-andafrica/tackling-covid-19-in-africa\# accessed 20 November 2020 
Martini and Chêne 2014 https://www.transparency.org/files/content/ corruptionqas/Approaches_to_curbing_corruption_in_tax_administration_i n_Africa_2014.pdf

Martini M and Chêne M 2014 Approaches to Curbing Corruption in Tax Administration in Africa https://www.transparency.org/files/content/ corruptionqas/Approaches_to_curbing_corruption_in_tax_administration_i n_Africa_2014.pdf accessed 20 November 2020

Ndegwa 2020 https://allafrica.com/stories/202009070230.html Ndegwa A 2020 Africa: How Billions Worth of Covid-19 Funds were Stolen in Africa https://allafrica.com/stories/202009070230.html accessed 27 November 2020

Ndujihe, Nnochiri and Ajayi 2016 https://www.vanguardngr.com/2016/03/ alleged-false-declaration-cct-declines-quash--charge-saraki/

Ndujihe C, Nnochiri I and Ajayi O 2016 Alleged False Declaration: FRN vs Tinubu was in Error - CCT https://www.vanguardngr.com/2016/03/allegedfalse-declaration-cct-declines-quash--charge-saraki/ accessed 25 May 2021

Njoku et al 2020 https://guardian.ng/news/hard-times-in-buharis-changeregime/

Njoku L et al 2020 Hard Times in Buhari's Change Regime https://guardian.ng/news/hard-times-in-buharis-change-regime/ accessed 30 November 2020

OECD $2021 \quad$ https://www.oecd.org/tax/centre-for-tax-policy-andadministration-brochure.pdf

Organisation for Economic Co-operation and Development Centre for Tax Policy and Administration 2021 OECD Work on Taxation https://www.oecd.org/tax/centre-for-tax-policy-and-administrationbrochure.pdf accessed 25 May 2021

Okunogbe and Pouliquen 2018 http://pubdocs.worldbank.org/en/ 754541528721176191/Okunogbe-Pouliquen-EfilingTaj-2018May21.pdf Okunogbe $O$ and Pouliquen V 2018 Technology, Taxation, and Corruption: Evidence from the Introduction of Electronic Tax Filing http://pubdocs.worldbank.org/en/754541528721176191/Okunogbe-

Pouliquen-EfilingTaj-2018May21.pdf accessed 13 January 2021 
Page 2018 https://carnegieendowment.org/2018/07/17/new-taxonomy-forcorruption-in-nigeria-pub-76811

Page M 2018 A New Taxonomy for Corruption in Nigeria https://carnegieendowment.org/2018/07/17/new-taxonomy-for-corruptionin-nigeria-pub-76811 accessed 10 November 2020

Phillip 2003 https://allafrica.com/stories/200303240846.html

Phillip A 2003 Nigeria: Travails of the Auditor-General https://allafrica.com/stories/200303240846.html accessed 1 December 2020

Punch Editorial Board 2020 https://punchng.com/resolving-high-profilecorruption-cases/

Punch Editorial Board 2020 Editorial: Resolving High Profile Corruption Cases https://punchng.com/resolving-high-profile-corruption-cases/ accessed 10 November 2020

PwC 2016 https://www.pwc.com/ng/en/assets/pdf/impact-of-corruption-onnigerias-economy.pdf

PricewaterhouseCoopers 2016 Impact of Corruption on Nigeria's Economy https://www.pwc.com/ng/en/assets/pdf/impact-of-corruption-on-nigeriaseconomy.pdf accessed 23 November 2020

Raffaele 2020 https://www.voanews.com/episode/nigerians-protestincrease-electricity-and-fuel-prices-amid-coronavirus-pandemic-4421451 Raffaele R 2020 Nigerians Protest Increase in Electricity and Fuel Prices Amid Coronavirus Pandemic https://www.voanews.com/episode/nigeriansprotest-increase-electricity-and-fuel-prices-amid-coronavirus-pandemic4421451 accessed 25 November 2020

Transparency International 2020 https://www.transparency.org/en/what-iscorruption

Transparency International 2020 What is Corruption? https://www.transparency.org/en/what-is-corruption accessed 10 November 2020

Transparency International 2020 https://www.transparency.org/files/ content/pages/2019_CPI_Report_EN.pdf

Transparency International 2020 Corruption Perceptions Index 2019 https://www.transparency.org/files/content/pages/2019_CPI_Report_EN.p df accessed 15 November 2020 
Umar 2012 http://allafrica.com/stories/201209290446.html

Umar Y 2012 Nigeria: Code of Conduct Tribunal Lacks Enough Funds to Fight Corruption http://allafrica.com/stories/201209290446.html accessed 25 November 2020

UNECA 2016 https://repository.uneca.org/bitstream/handle/10855/23012/b11560794.pdf United Nations Economic Commission for Africa 2016 Measuring Corruption in Africa: The International Dimension Matters - African Governance Report IV https://repository.uneca.org/bitstream/handle/ 10855/23012/b11560794.pdf accessed 25 November 2020

UNECA and AUABC 2017 https://repository.uneca.org/bitstream/handle/ 10855/23273/Bib-28380.pdf

United Nations Economic Commission for Africa Governance and Public Administration Division and African Union Advisory Board on Corruption 2017 Combating Corruption, Improving Governance in Africa: Regional Anti-Corruption Programme for Africa (2011-2016) https://repository.uneca. org/bitstream/handle/10855/23273/Bib-28380.pdf accessed 10 November 2020

UNODC 2019 https://www.unodc.org/documents/data-and-analysis/ statistics/corruption/nigeria/Corruption_in_Nigeria_2019_standard_res_11 MB.pdf

United Nations Office on Drugs and Crime 2019 Corruption in Nigeria: Patterns and Trends - Second Survey on Corruption as Experienced by the Population https://www.unodc.org/documents/data-and-analysis/statistics/ corruption/nigeria/Corruption_in_Nigeria_2019_standard_res_11MB.pdf accessed 25 November 2020

USIP 2010 https://www.usip.org/sites/default/files/Adan/NPEC1011_ StudyGuide_combined.pdf

United States Institute of Peace 2010 Governance, Corruption, and Conflict https://www.usip.org/sites/default/files/Adan/NPEC1011_StudyGuide_com bined.pdf accessed 25 November 2020

Vanguard Editor 2003 https://allafrica.com/stories/200302250568.html Vanguard Editor 2003 Nigeria: AG Auditor-General's Removal https://allafrica.com/stories/200302250568.html accessed 13 January 2021 
Wald 2018 https://www.weforum.org/agenda/2018/04/governments-joindigital-payment-revolution-fight-corruption/

Wald T 2018 Governments can Fight Corruption by Joining the Digital Payment Revolution https://www.weforum.org/agenda/2018/04/ governments-join-digital-payment-revolution-fight-corruption/ accessed 13 January 2021

\section{List of Abbreviations}

AHRLJ
AJBMR
Ann Surv Int'l \& Comp L
AUABC
CCB
CPA
EFCC
ENDSARS
FRN
GJHSS
GJISS

Harv Hum Rts $J$

IJARAFMS

IJIDPS

IJIRSET

IJMA

IJSSH

IJSSHR

IMF

IOSR-JHSS
African Human Rights Law Journal

Arabian Journal of Business and Management Review

Annual Survey of International and Comparative Law

African Union Advisory Board on Corruption

Code of Conduct Bureau

Critical Perspectives on Accounting

Economic and Financial Crimes Commission

End Special Anti-Robbery Squad

Federal Republic of Nigeria

Global Journal of Human-Social Science

Global Journal of Interdisciplinary Social Science

Harvard Human Rights Journal

International Journal of Academic Research in Accounting, Finance and Management Sciences

International Journal of Innovative Development and Policy Studies

International Journal of Innovative Research in Science, Engineering and Technology

International Journal of Maternal and Child Health and AIDS

International Journal of Social Science and Humanities

International Journal of Social Sciences and Humanities Reviews

International Monetary Fund

IOSR Journal of Humanities and Social Science 


\begin{tabular}{|c|c|}
\hline J Ec Behav \& Org & $\begin{array}{l}\text { Journal of Economic Behaviour and } \\
\text { Organization }\end{array}$ \\
\hline JEF & Journal of Economics and Finance \\
\hline JEP & Journal of Economic Perspectives \\
\hline JLERI & Journal of Legal, Ethical and Regulatory Issues \\
\hline JMAS & Journal of Modern African Studies \\
\hline JOTA & Journal of Tax Administration \\
\hline JPID & $\begin{array}{l}\text { Journal of Poverty, Investment } \\
\text { Development }\end{array}$ \\
\hline JSC & Journal of Social Change \\
\hline MRA & Media Rights Agenda \\
\hline NNPC & Nigerian National Petroleum Corporation \\
\hline OECD & $\begin{array}{l}\text { Organisation for Economic Co-operation and } \\
\text { Development }\end{array}$ \\
\hline Pak Dev Rev & Pakistan Development Review \\
\hline $\mathrm{PwC}$ & PricewaterhouseCoopers \\
\hline UNECA & $\begin{array}{l}\text { United Nations Economic Commission for } \\
\text { Africa }\end{array}$ \\
\hline UNODC & United Nations Office on Drugs and Crime \\
\hline USIP & United States Institute of Peace \\
\hline $\begin{array}{l}\text { USV Ann Econ Publ } \\
\text { Adm }\end{array}$ & $\begin{array}{l}\text { The USV Annals of Economics and Public } \\
\text { Administration }\end{array}$ \\
\hline
\end{tabular}

